\title{
A new typical finding in late gadolinium enhanced images for the diagnosis of endomyocardial fibrosis - the double $\mathrm{V}$ sign
}

Adriano C Carneiro ${ }^{*}$, Roberta I Mochiduky, Leonardo F Zancaner, Estevan V Cabeda, Valeria M Moreira, Mario S Ribeiro, Alexandre V Villa, Roberto Kalil, Filho, Vera M Salemi, Charles Mady, Carlos E Rochitte

From 2011 SCMR/Euro CMR Joint Scientific Sessions

Nice, France. 3-6 February 2011

\section{Introduction}

Endomyocardial fibrosis (EMF) is a restrictive cardiomyopathy presenting with ventricular apical filling, possibly containing fibrotic tissue with thrombus and/or calcification. Late gadolinium enhancement (LGE) can detect apical fibrosis in EMF patients, as a hyper intense linear image usually in a letter "V" like shape pointing to the ventricular apex. Recently, we have observed a pattern of a double layer hyper and hypo intense in LGE images, also in a "V" like shape, possibly corresponding to fibrosis plus thrombus/calcification.

\section{Purpose}

Our objective was to investigate the frequency of fibrosis (single $\mathrm{V}$ ) and fibrosis associated to thrombus/calcification (double V) in a group of patients with EMF.

\section{Methods}

We retrospectively studied 44 patients with confirmed EMF that had undergone CMR exam in a $1.5 \mathrm{~T}$ scanner (GE Signa, CVi) during clinical investigation. CMR exam included cine-SSFP with standard parameters, and LGE images acquired $10 \mathrm{~min}$ after $0.2 \mathrm{mmol} / \mathrm{kg}$ of gadolinium-based contrast and with the parameters: TR $7.2 \mathrm{~ms}$, TE $3.2 \mathrm{~ms}$, matrix $256 \times 192$, flip angle $20^{\circ}$ and inversion time (TI) 150 to $250 \mathrm{~ms}$, number of excitations 2 and acquisition in every heart beat ( 1 RR). We adjusted TI to null the signal from normal myocardium after contrast. Two observers independently classified LGE long-axis images from all patients in 4 categories: absence of fibrosis, single $\mathrm{V}$ fibrosis, double $\mathrm{V}$ fibrosis plus thrombus/calcification and fibrotic tissue without $\mathrm{V}$ shape.
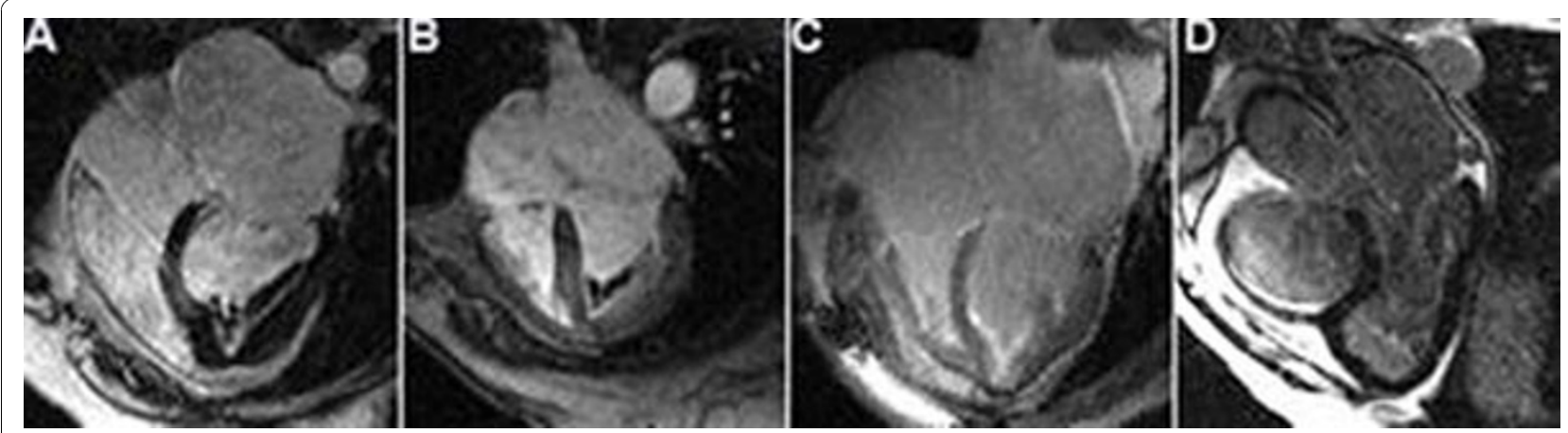

Figure 1

Heart Institute -InCor- University of Sao Paulo Medical School, Sao Paulo, Brazil

(c) 2011 Carneiro et al; licensee BioMed Central Ltd. This is an open access article distributed under the terms of the Creative Commons 


\section{Results}

From the 44 patients, with mean age of $60 \pm 11.8$ years old, 36 (82\%) were female. Thirty-nine patients (89\%) presented apical fibrosis on the LGE images. From those, 21(54\%) had the typical aspect of double-layered $\mathrm{V}$ shape of fibrosis plus thrombus/calcification, 11(28\%) had only apical fibrosis (single V) and only 7 (18\%) had fibrosis without the $\mathrm{V}$ shape $(\mathrm{p}<0.001$ for the $\mathrm{V}$ sign, Figure 1: A/B, C and D, respectively).

From the 44 patients, $16(36 \%)$ had a biventricular, 22 (50\%) LV only, and 6 (14\%) had RV only involvement by apical filling.

\section{Conclusion}

In conclusion, more than half of patients (54\%) with confirmed EMF and fibrosis presented an LGE imaging finding of apical filling associated to a hyper and hypo intense double-layered image, in a letter "V" like shape pointing to the ventricular apex (double $\mathrm{V}$ sign). Our data suggest that the double $\mathrm{V}$ sign can be considered a typical finding in EMF patients. This realization might help in the differential diagnosis with other apical filling conditions, such as apical hypertrophic cardiomyopathy, apical thrombus, and others.

Published: 2 February 2011

doi:10.1186/1532-429X-13-S1-O40

Cite this article as: Carneiro et al:: A new typical finding in late gadolinium enhanced images for the diagnosis of endomyocardial fibrosis - the double V sign. Journal of Cardiovascular Magnetic Resonance 2011 13(Suppl 1):O40.
Submit your next manuscript to BioMed Central and take full advantage of:

- Convenient online submission

- Thorough peer review

- No space constraints or color figure charges

- Immediate publication on acceptance

- Inclusion in PubMed, CAS, Scopus and Google Scholar

- Research which is freely available for redistribution

Submit your manuscript at www.biomedcentral.com/submit
C) Biomed Central 